\title{
An Analysis of the Differences Between Praise and Flattery by the Co-operative Principle
}

\author{
Changfeng Zhu ${ }^{1}$ \\ ${ }^{1}$ Foreign Language Department, Guangzhou College of Business and Technology, Guangdong, China \\ Correspondence: Changfeng Zhu, Foreign language Department, Guangzhou College of Business and \\ Technology, Guangdong, China. E-mail: 747223356@qq.com
}

Received: November 20, 2017 Accepted: January 3, 2018 Online Published: February 8, 2018

doi:10.5539/ells.v8n1p61 URL: https://doi.org/10.5539/ells.v8n1p61

\begin{abstract}
This paper will distinguish praise and flattery based on the Gricean maxims of the Co-operative Principle and the four maxims. Through the comparative studies and typical instances, we found that Praise contains two necessary parts: the facts and their approval or admiring feelings of the addressee. Both of them should be quantity-proper, true, relevant and in a clear way; while flattery sits on opposite ends of a spectrum.
\end{abstract}

Keywords: praise, flattery, the Co-operative Principle

\section{Introduction}

Praise exists globally and occurs in all languages. It has been regarded as the most beautiful words in the world to content one's heart. It has the underlying social function of creating or reinforcing solidarity between the speaker and the addressee. This also confirms the idea of the Cooperative Principle, which has been extensively used in our social communication for all kinds of cooperative exchanges in our daily life. Therefore, this thesis will make a comparative study about praise and flattery in a theoretic framework of Grice's Co-operative Principle and the four maxims

\subsection{An Overview of the Research on Praise}

Praise has been said to "grease the social wheels" and thus to serve as "social lubricants" (Wolfson, 1983, p. 89), we all have given praise and we all occasionally receive it. It is used to enrich or even replace the greetings, to encourage or persuade your friends, to highlight your gratitude. It also induces friendly conversations, to avoid the embarrassments or erase conflicts. It is so important and commonly used in our social communication that everyone is eager to be skillful at it, which may also account for why it has received so much attention from a wide range of researchers working in different fields and with different languages, such as the study of different compliment responding strategies of English and Japanese (Daikuhara, 1986). Manes \& Wolfson (1981) made an influential investigation into the use of compliments among the middle class Americans, finding that the syntactic and semantic structure of praise is in certain regularity. Herbert (1990) and Holmes (1988) discovered that the genders also influence the praise. Some other researchers may also study its important function in teaching or its inter-cultural differences and so on. However, there is little attention to "praise" itself and the discrepancy between praise and flattery in use, which can really affect our communication.

\subsection{The Theoretical Frame}

Some three decades ago, H. P. Grice proposed the Cooperative Principle for the analysis of discourse in order to "find the conditions governing conversation": "We might formulate a rough general principle which participants will be expected to observe" (Grice, 1967, 1975, p. 45). Since then, this Cooperative Principle has been extensively used in discourse analysis. Indeed, its rhetorical application extends into all kinds of cooperative exchanges in our social communication. Grice (1975) noticed that "Our talk exchanges do not normally consist of a succession of disconnected remarks, and would not be rational if they did. They are characteristically, to some degree at least cooperative efforts; and each participant recognizes in them, to some extent, a common purpose or set of purposes, or at least a mutually accepted direction". In other words, we seem to follow some principle like the following: 


\section{1). The Maxim of Quantity:}

Make your contribution as informative as is required (for the current purposes of the exchange)

Do not make your contribution more informative than is required

2). The Maxim of Quality:

Try to make your contribution one that is true.

Do not say what you believe to be false.

Do not say that for which you lack adequate evidence.

3). The Maxim of Relation:

Be relevant to the topic of the current exchanges.

4). The Maxim of Manner:

Be perspicuous

Avoid obscurity of expression

Avoid ambiguity

Be brief

Be orderly

The basic assumption of this theory is that any discourse, whether written or spoken, is a joint effort. Both the speaker and the hearer have to follow certain pragmatic, syntactic, and semantic rules in order to communicate effectively. They have to cooperate. Grice (1975) says "Firstly, at a purely practical level, what may seem explicit and obviously clear to the speaker may not be so for the hearer: there seems to be too great an assumption of shared knowledge/common ground here". The four maxims appear simple, straightforward, and commonsensical at first sight. However, these principles can be observed at work on a highly technical level in language. If a speaker violates one or more of these fundamental maxims, the communication breaks down. If a speaker obeys their observance, it will be a successful discourse.

\section{The Analysis of the Differences between "Praise" and "Flattery" by the Four Maxims}

All of us expect to receive praise instead of flattery and give praise to others; however, it is really difficult for us to succeed in every situation for every time. But if we judge others' praise by some commonly conversational principle - Co-operative Principle, we may easily discover whether their praise is true or not. Then, by this way, we can quickly grasp the differences between praise and flattery which, in turn, can also help us make our own effective praise.

\subsection{The Definitions of "Praise" and "Flattery"}

Praise is an invisible tie to connect you with your friends or community. It is a kind of transition of good feelings or attitudes towards others. However, if your praise is beyond the facts or a little too much, too often, you may get an opposite results, for it may arouse others' dislike or suspicion of your intention. Then, how should we make our praise appropriately and effectively accepted? First, we have to make a clear concept of the word and distinguish it from its synonyms such as compliment and flattery. According to Webster's Dictionary of English language (1979) "compliment" is defined as "to praise, to flatter by expressions of approbation, esteem or respect; to congratulate". From the definition of Webster, we can see that the denotative meaning of compliment contain both the positive and negative meanings, though in reality, we usually use it as a positive word. While "praise" is absolutely and commonly regarded as a positive term, in The Advanced Learners' Dictionary of Current English, it means "to speak with approval of or speak highly of or glorify worship". To put it more simply, it means "to express approval or admiration for someone or something, esp. publicly". From the meanings of the word "approval" which means "the fact of believing that someone or something is good or is doing the right thing" and of the word "admiration" which means "to have a high opinion of somebody because of a quality they have or because of something they have done", We can see "praise" is a totally positive and acceptable action, While "flattery" is an opposite one, revealing a negative, immoral and criticized behavior. It has several means: (1) to praise insincerely, esp in order to win favour or reward; (2) to make to appear more attractive, etc, than in reality; (3) to play upon or gratify the vanity of (a person); (4) to congratulate or deceive (oneself). From the definitions of these words, there is really a difference among compliments, praise and flattery, but in practice they are hard to be distinguished. Because of the complications of the situations, we usually feel puzzled and confused by them. We don't know how to praise our friends, relatives or colleagues or superiors just 
because we are afraid that our praise will develop into or be mistaken as flattery. Another extreme is that some of us praise overly. They may exaggerate or amplify their praise which makes others dislike it. Therefor, it is really necessary for us to distinguish them and master them correctly to smooth our life. From the next part, we will use this way to detect flattery and praise in different situations.

\subsection{The Difference between Praise and Flattery in Light of Quantity Maxim}

Grice (1975) holds that "The first of these maxims is known as the quantity maxim, which states one's contribution should provide sufficient, but not too much information." If one does not provide enough information during a conversation, he or she might be viewed as incompetent and uninformed. On the other hand, providing too much information during the course of a conversation can be perceived as overwhelming and insignificant to the other person. This maxim means that the speaker has to include the only information that the addressee requires to understand.

According to his explanation of the quantity maxim, we can classify our behaviors of praise into three kinds of situations: under-praise (non-praise), proper-praise (praise), over-praise (flattery). If we do not mention the things others do for you or just state the facts without our emotions or feelings. It can be judged as under-praise which is regarded as incompetent and uninformed, for we do not provide "enough information" about praise according to the elements required by praise, therefore, the addressee will not understand what the speaker is trying to "say", then, it becomes non-praise. Sometimes we want to please others by praising, but our words do not take effect, because we do not show our emotions or enthusiasm.

For example, Xiao Wang was intended to praise Xiao Li for his cleverness in math, but he failed because he did not show such kind of admiring feeling of Xiao Li.

小王：你这道题是用很复杂的微积分做的。(Xiao Wang: You solve the problem by the complicated calculus)

小李: 是的。(毫无表情) (Xiao Li: Yes. (blankly))

Praise is quantity-proper. It provides adequate information, including the facts and their approval or admiring feelings of the addressee as required. While flattery is quantity-extra or without facts, for flattery is usually a deluge of information about the excellence or even without factual details. It provides too much so as to be perceived as overwhelming and insignificant to the addressee. That's also why we usually feel others unceasing overpraise is not true because we doubt whether we really do so many good deeds or possess so many excellent characteristics that others count. One of the evidence is from the author's observation of the introductions of famous lecturers in universities. Before the lecturing, if the famous expert is introduced by his many published articles and various tittles in different organizations. The hearers usually doubt and despise it though what they introduced is really true facts, related to the professor, and in a clear, orderly way. For the hearers were flooded by too much information that they naturally took it as overpraise, i.e. flattery. On the other hand, when one expert is introduced by one of his most outstanding achievements, the hearers usually believe it, remembering it and showing their admiration unconsciously. With the contrastive results, it obviously reveals that praise is really different from flattery in the perspective of the quantity maxim. Praise is quantity-proper while flattery is quantity-extra.

\subsection{The Difference between Praise and Flattery in Light of Quality Maxim}

The quality maxim states that one's contribution to a conversation should be truthful. In linguistic terms, truthfulness refers to the importance of only making statements we believe to be true. "You violate the quality maxim when you deliberately lie or communicate in a way that does not reflect an honest intention" (Grice, 1975). From the definitions of flattery, we know it means the addresser praises insincerely by showing more than the truth, which, on the other hand, reveals praise is always sincere and true. Obviously, when we praise others, we always refer to the things they had already done or the facts they do possess. While to flatter, the addressers usually exaggerate or amplify the facts which may lack of evidence or even contradict to the truth. For example, the following is a conversation between two women, one is twenty, and the other is forty years old who is a superior of the first one.

女 1: 你皮肤可真好啊, 跟姑娘似的。(W1: Your skin is so tender, just like a young girl's.)

女 2: 怎么可能, 我女儿是姑娘还差不多。(W2: How can it be? My daughter may be.)

In this conversation, the first woman obviously violates the quality maxim, for the second woman is not a young girl as she described. That is also why the second woman disagree her. The words of the first woman are obviously a piece of dishonest exaggerated flattery which is perceived by the addressee, so it cannot please the addressee. Another example is followed. 
华茹: 妈我真是发现你是全世界第一善良的人。(Hua Ru: Mom, I’ve found you are the kindest person in this world.)

华母: 去你的吧。(Hua Mu: You are flattering me.)

Though this conversation happened in relatives as one is the daughter, another is mother and the daughter seems really want to show her sincere praise for the things her mother done for her, but still negated by the mother, because her words of praise are too exaggerated which can not be regarded as a truth. Therefore, we can see to make an effective praise is not really easy, even though we are sincere and honest. If we cannot master the degree of quality but inflate the truth, then, we will fall into the flattery. That is also why the responses to compliments have Question and Disagreement (Herbert, 1990, pp. 208-209).

\subsection{The Difference between Praise and Flattery in Light of Relation Maxim}

Relevance is an extremely important principle in linguistics, and quite a few books have been written just on the role of relevance in language. "In the context of H.P. Grice's Cooperative Principle, the demand for relevance simply means that the speaker should only include information in his communication that is relevant to the topic under discussion" (Bethan Davies, 2000), that is, the speaker should avoid including unnecessary, unrelated redundant information in his contribution. To distinguish praise and flattery by this maxim, we can say praise is relevant while flattery contains both relevant and irrelevant parts. It seems very easy to distinguish them. While in a complicated situation, it may be very difficult to divide which is relevant and which is irrelevant for there is an invisible bridge between them. Therefore, we usually extend our praise in a speech to somewhat flattery, Esp. in a complimentary meeting, when we praise someone who really has so many kinds of excellence, we may unconsciously slip into flattery, to talk some irrelevant facts which may spoil the hearers' interest. A true praise which can make others feel sincerity is the most closely related things. For example, the following is a conversation in a grocery between the male storekeeper and a female buyer who is the cadre in their community.

男: 你不光是个关心老百姓的好干部, 你还是个好主顾。(M: You are not only a good cadre but also a good client.)

\section{女: 是, 我就是一个好干部。(W: Yes, I am a good cadre.)}

From the conversation, we can see the male seller does a very good job. He tried his best to make his praise relevant which make the addressee agreeably accept it.

Another common evidence is that when we want to show our gratitude for other's help by praising them, we had better praise them by the favor they had given to us rather than praise their benevolent behaviors in their whole life or the favors they given to others, because they may think you are just a flatterer who want to get more advantages in later days.

\subsection{The Difference between Praise and Flattery in Light of Manner Maxim}

According to Grice, our utterance should be clear, brief, and orderly without obscurity and ambiguity. Only in this way, can the hearers understand our meaning correctly. In light of this maxim, we can say praise is somewhat comparatively clear and brief which can make the hearer figure out the addresser's good intention, while flattery is more obscure and ambiguous which can not reveal clearly the addresser's "good intention", Esp. in Asian cultures, in which people usually use indirect speeches to show both their approval and disagreements. Therefore, it is much difficult to distinguish whether it is praise or flattery in these situations. Anyway, what we are sure is the flattery is too obscure that we usually doubt its sincerity or take it as an irony.

For example:

Situation A: 队员: 邢队, 你真好。(M: Captain, you are really good.)

邢凯: 学会拍马屁了(C: when you learned to flatter others?)

Situation B: 宋建平: 小枫, 你是个好人, 是个诚实的人。(S: Xiaofeng, you are a good man, an honest man.) 林小枫微点头。(Lin Xiaofeng nodded acceptably.)

These two situations make a contrast. We can say both addressers want to show their gratitude and both express the same meaning in their utterance while the addresser in situation A is criticized as flattery but the addresser in situation B is accepted. Because the utterance of the addresser in situation A is too general and obscure that the hearer doubt its sincerity, but the utterance of the addresser in situation B is more specific and clear that make the hearer believe he is sincere and the words he said are true. Here is another example to illustrate the advantages of clearness in praise:

谢敏：你是个漂亮的警察局长妈妈。(X: You are a beautiful police-chief mother.) 


\section{任常霞：这话我爱听。(R: I like it.)}

The addresser makes her praise as clear and specific as it is which delights the addressee.

\section{Conclusion}

Praise is important as well as frequent in everyday social interactions all over the world. Appropriate praise behavior is crucial for the establishment and maintenance of interpersonal relationships. So we should have a clear concept of it and distinguish it from flattery based on Gricean Co-operative Principle and the four maxims. To make our praise as the maxims required: informative enough, true; relevant and in a clear way so as to lead a happy and smooth life.

This thesis has made an exploratory and primary research about praise and flattery; however, it may be deficient in several aspects. Generally speaking, the thesis only studies the differences between praise and flattery from the perspective of Gricean Co-operative Principle and the four maxims. Other perspectives like culture, psychology, sociology, etc. are not taken into consideration. Second, since the four maxims of Grice are not absolute, some of them may self-contradictory; therefore, the differences which are judged by the maxims are not absolute, either.

\section{Acknowledgments}

I am indebted to Professor Ma Min for detailed comments on this paper.

\section{References}

Bethan, D. (2000). Grice's cooperative principle: getting the meaning across. Leeds Working Papers in Linguistics\& Phonetics (pp. 361-378).

Daikuhara, M. (1986) A study of compliments from a cross-cultural perspective: Japanese vs American English Working Papers in Educational Linguistics, 2(2), 103-134

Herbert, R. K. (1990). Sex based differences in compliment behavior. Language in Society, 19(2), 201-224. https://doi.org/10.1017/S0047404500014378

Holms, J. (1998). Paying compliments: a sex-preferential positive politeness strategy. Journal of Pragmatics. Retrieved from http://www.sciencedirect.com/science/article/pii/0378216688900057

http://www.thefreedictionary.com/Flatter

The Advanced Learners' Dictionary of Current English. (1963). U.K.: Oxford Press.

Webster's Dictionary of English language. (1995). U.S.: Merriam Webster.

Wolfson, N. (1983) An Empirically based analysis of complimenting in American English. Sociolinguistics and Language Acquisition. MA: Newbury House.

Wolfson, N., \& Manes, J. (1980). The compliment as a social strategy. papers in linguistics. International Journal of Human Communication, (3), 389-410. https://doi.org/10.1080/08351818009370503

Wolfson, N., \& Manes, J. (1981). The compliment formula. Conversational routine: explorations in standardized communication situations and prepatterned speech (pp. 96-102).

Hu, Z. L. (2002). Linguistics: A Course Book. Beijing: Peking University Press.

\section{Copyrights}

Copyright for this article is retained by the author(s), with first publication rights granted to the journal.

This is an open-access article distributed under the terms and conditions of the Creative Commons Attribution license (http://creativecommons.org/licenses/by/4.0/). 